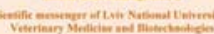
然 25is: 10 incing ine

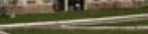

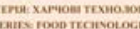
Том 21 Nit 91
Науковий вісник Яьвівського національного університету ветеринарної медицини та біотехнологій імені С.3. Гжицького. Серія: Харчові технології

\author{
Scientific Messenger of Lviv National University
} of Veterinary Medicine and Biotechnologies.

Series: Food Technologies

UDC 637.33

\title{
Improve the technology of brynza from sheep's milk by adding a bioprotective culture
}

I. Skulska, O. Tsisaryk

Stepan Gzhytskyi National University of Veterinary Medicine and Biotechnologies Lviv, Ukraine

Article info

Received 29.01.2019

Received in revised form 04.03 .2019

Accepted 05.03.2019

Stepan Gzhytskyi National University of Veterinary Medicine and Biotechnologies Lviv,

Pekarska Str., 50, Lviv, 79010, Ukraine.

Tel.: +38-097-854-61-38

E-mail: inna_skulska@ukr.net
Skulska, I., \& Tsisaryk, O. (2019). Improve the technology of brynza from sheep's milk by adding a bioprotective culture. Scientific Messenger of Lviv National University of Veterinary Medicine and Biotechnologies. Series: Food Technologies, 21(91), 104-109. doi: 10.32718/nvlvet-f9118

Brynza is a compulsory product of the daily diet of the inhabitants of the Carpathians and a favorite product for many other consumers, but contains from 4 to $7 \%$ of salt. The consumption of a large amount of salt can cause many diseases. The current task of the present is to find ways to extend the shelf life of products provided that the content of their kitchen salt is reduced. One of the ways to reduce the content of the salt is the partial replacement of potassium chloride. The aim of the research was to investigate the course of microbiological processes in brine cheese, the traditional technology of which was improved by 20 and 30\% replacement of the salt with potassium chloride in brine and using the bioprotective culture, as well as determining the storage time of the cheese. Preparates used by Chr. Hansen: were used to ferment RSF-742 fermentation culture containing 2 strains of mesophilic and 2 strains of thermophilic microflora, Fresh-Q bioprotection culture and enzyme preparation - CHY-MAX. The action of the Fresh-Q bioprotection culture is aimed at inhibiting the development of yeast and mold, which includes L. rhamnosus. There were made 6 samples of cheese from sheep's milk: $K$-control sample using the kitchen salt (sodium chloride); D1 and D2 - brynza, made of 20 and 30\% by substitution of sodium chloride with potassium chloride, respectively; $K F$ - cheese made using sodium chloride and Fresh-Q bioprotection culture; DF1 and DF2 - brynza, made of 20 and 30\% sodium chloride replaced by potassium chloride, respectively, using Fresh-Q. It has been established that the use of Fresh-Q bioprotection culture has a greater effect on organoleptic properties than the replacement of the kitchen salt. According to the results of the score, the highest score was obtained with samples using a bioprotective culture. It is proved that the replacement of the kitchen salt and the use of Fresh-Q provides a high quality product and its compliance with the requirements of regulatory documentation. The study of the course of microbiological processes confirms the expediency of improving the traditional technology of the production of brynza by partial replacement of the kitchen salt with potassium chloride and the addition of Fresh-Q. The research results confirm that the cheese storage period is lengthened by 10 days in samples made using Fresh-Q bioprotection culture.

Key words: brynza cheese, microbiological indices, bioprotection culture, yeast, mold, sodium chloride, potassium chloride.

\section{Удосконалення технології бринзи 3 овечого молока шляхом додавання біозахисної культури}

\author{
І.В. Скульська, О.Й. Цісарик
}

Львівський національний університет ветеринарної медицини та біотехнологій імені С.3. Гжицького, м. Львів, Україна

Бринза є обов'язковим продуктом щуоденного раціону мешканців Карпат та улюбленим продуктом для багатьох інших споживачів, проте містить від 4 до 7\% кухонної солі. Споживання великої кількості кухонної солі може спричинити виникнення багатьох захворювань. Актуальним завданням нині є знайти шляхи подовження терміну зберігання продуктів за умови зниження вмісту у них кухонної солі. Одним із шляхів зниженням вмісту кухонної солі є часткова заміна їі хлоридом калію. Метою досліджень було досліди- 
ти перебіг мікробіологічних процесів у розсольному сирі бринза, традиційну технологію якої удосконалювали шляхом 20 та $30 \%$ заміни кухонної солі хлоридом калію у розсолі та використанням біозахисної культури, а також визначити термін зберігання бринзи. Для сквашування використано препарати фірми Chr. Hапsеп: заквашувальну культуру RSF-742, яка містить у своєму складі 2 шттами мезофільної і 2 штами термофільної мікрофлори, біозахисну культуру Fresh-Q та ферментний препарат СНY-МАХ. Дія біозахисної культури Fresh-Q спрямована на пригнічення розвитку дріжджів і плісені, до складу якої входить L. rhaтпоsиs. Було виготовлено 6 зразків бринзи з овечого молока: $K$ - контрольний зразок із використанням кухонної солі (хлорид натрію); Д1 і Д2 - бринза, ияо виготовлена з 20 і 30\% заміною хлориду натрію хлоридом калію відповідно; KF - бринза, шзо виготовлена із використанням хлориду натрію та біозахисної культури Fresh-Q; ДF1 і ДF2 - бринза, щчо виготовлена з 20 і 30\% заміною хлориду натрію хлоридом калію відповідно та використанням Fresh-Q. Встановлено, ше застосування біозахисної культури Fresh-Q зумовлює більший вплив на органолептичні властивості порівняно із заміною кухонної солі. За результатами балової очінки найбільшу кількість балів отримали зразки з використанням біозахисної культури. Доведено, шьо заміна кухонної солі та застосування препарату Fresh-Q забезпечує високу якість продукту $і$ відповідність його вимогам нормативної документації. Дослідження перебігу мікробіологічних процесів підтверджують доиільність удосконалення традииійної технології виготовлення бринзи шляхом часткової заміни кухонної солі хлоридом калію та додавання препарату Fresh-Q. Результати досліджень підтверджують те, щзо термін зберігання сиру подовжується на 10 діб у зразків, які виготовлені з використанням біозахисної культури Fresh-Q.

Ключові слова: бринза, мікробіологічні показники, біозахисна культура, дріжджі, плісень, хлорид натрію, хлорид калію.

\section{Вступ}

Для нас, українців і наших сусідів - молдаван, болгар і румунів традиційними харчовими продуктами $є$ саме молочні, зокрема сир бринза, якою залюбки смакують діти і дорослі. Важливе значення при цьому належить відносно нескладній технології їі приготування (Gudkov, 2003).

Обираючи свій улюблений продукт, сучасний споживач віддає перевагу користі, енергетичній цінності їжі і, безперечно, смако-ароматичним особливостям. Завдяки цьому асортимент розсольних сирів постійно розширюється.

Бринзу зараз вживають і як самостійний продукт, i як компонент безлічі страв. Завдяки короткому терміну визрівання (20 діб) можна досить швидко отримати смачний та ароматний сир. Бринза визріває у розсолі, концентрація солі у якому сягає 18-22\%, відповідно вміст солі у сирі становить 4-7\% (DSTU 7065:2009, 2010; Skulska \& Cisaryk, 2015). Кухонна сіль відіграє значну роль у перебігу біохімічних та мікробіологічних процесів під час визрівання сиру, вона є добрим консервантом. Однак, надлишкове споживання кухонної солі спричиняє розлади роботи серцевосудинної системи та опорно-рухового апарату (Skulska \& Cisaryk, 2015). Сьогодні світовою тенденцією здорового харчування є обмеження споживання кухонної солі, для цього розроблено низку програм (Ayyash \& Shah, 2011; Brynza zi znyzhenym vmistom kuhonnoji soli, 2016).

Актуальність теми. Оскільки важливою роллю кухонної солі у харчових продуктах є саме роль консерванта, зниження іiі вмісту може призвести до передчасного псування продукту (Аууаsh \& Shah, 2011; Ayyash et al., 2012). Важливим завданням є знайти шляхи подовження терміну зберігання продуктів за умови зниження вмісту у них кухонної солі.

Аналіз літературних даних свідчить про те, що знизити рівень споживання кухонної солі у продуктах харчування можна шляхом часткової заміни кухонної солі (хлорид натрію - $\mathrm{NaCl}$ ) хлоридом калію (KCl) у співвідношеннях 3:1, 1:1, 1:3 Ayyash, Sherkat, Shah, (2012). Дослідження проводилися на твердих сирах i показали позитивну динаміку змін щодо перебігу біохіміч ни процесів, які у них відбуваються протягом визрівання і зберігання (Ayyash \& Shah, 2011; Lu
\& McMahon, 2015). У білому сирі Akawi дослідження показали, що за заміни кухонної солі хлоридом калію у співвідношенні 3:1 твердість, клейкість і здатність до злипання у сирі зменшилися, а за даними проведеної сенсорної оцінки досліджуваного сиру зменшилася гіркота і солоність; також спостерігалося зниження вмісту розчинного кальцію і натрію, але кількість розчинних калію і фосфору, вмісту лимонної, молочної та оцтової кислот зросла на 30 добу зберігання при температурі $(4 \pm 1){ }^{\circ} \mathrm{C}$. Часткова заміна хлориду натрію хлоридом калію значно вплинула на зростання мікробної та протеолітичної активності. Заміна солі незначно вплинула на структуру досліджуваного сиру і його хімічний склад. Щодо інших варіантів співвідношень, то виявлено негативний вплив на якісні показники сиру (Ayyash et al., 2012).

Часткова заміна хлориду натрію хлоридом калію при виготовленні сиру чеддер призводить до ферментативної і мікробної стабільності завдяки підтримці необхідного показника активності води (AW). Shakeel-Ur-Rehman i ін. вивчали вплив заміни солі, додаючи дріжджевий екстракт. Дослідження показали, що використання цього екстракту негативно позначилося на розвитку молочнокислих бактерій. Варто зазначити, що сир характеризувався більш зрілим смаком та горіховим, злегка фруктовим ароматом. Вчені очікували появи гіркоти через використання хлориду калію, однак результати проведеної сенсорної оцінки довели протилежне (Grummer et al., 2013).

Також $є$ відомості щодо використання хлориду калію у технології виготовлення сиру Halloumi. Встановлено, що заміна солі не впливає на вміст вологи в сирі, масову частку жиру, що суперечить дослідженням M.M. Ayyash, N.P. Shah (Ayyash \& Shah, 2011), імовірно, через різницю в концентрації розчину солі в розсолі (18\% у досліджуваному сирі проти $10 \%$ у сирі Halloumi). Результати досліджень реологічних показників вказують на те, що заміна солі впливає на твердість, пружність сиру при розжовуванні в кінці терміну визрівання. Вказані показники погіршуються у випадку більшого відсотку заміни. Подібні результати були отримані від Parademas i Robinson, які виявили, що структура сиру Halloumi дещо погіршилася в кінці визрівання (Kamleh et al., 2012).

Тому, враховуючи не завжди одностайні результати щодо зниження концентрації $\mathrm{NaCl}$ та часткової 
його заміни $\mathrm{KCl}$ у дослідженнях закордонних авторів, відсутність таких досліджень в Україні та актуальність проблеми, метою нашої роботи було вивчити вплив такої заміни при виробництві традиційного карпатського сиру бринза. Бринза є обов'язковим продуктом щоденного раціону мешканців Карпат та улюбленим продуктом для багатьох інших споживачів, тому свою увагу ми сфокусували саме на сирі цього виду щодо пошуку шляхів зменшення у ньому кухонної солі та одночасно подовження терміну зберігання.

Метою наших досліджень було дослідити перебіг мікробіологічних процесів у розсольному сирі бринза, традиційну технологію якої удосконалювали шляхом 20 та 30\% заміни кухонної солі хлоридом калію у розсолі та використанням біозахисної культури, а також визначити термін зберігання бринзи.

Для сквашування використано препарати фірми Chr.Hansen: заквашувальну культуру RSF-742, біозахисну культуру Fresh-Q та ферментний препарат CHY-MАХ. Дія біозахисної культури Fresh-Q спрямована на пригнічення розвитку дріжджів і плісені, до складу якої входить L. rhamnosus.

L. rhamnosus росте в молоці у вигляді довгих або коротких паличок товщиною 1,5 мкм, з'єднаних в ланцюжки. Часто виявляється зернистість клітин. Оптимальна температура росту близько $(30 \pm 1){ }^{\circ} \mathrm{C}$. На відміну від L. casei здатний рости при температурі $(45 \pm 1){ }^{\circ} \mathrm{C}$, розмножуватися в середовищі, що містить $6 \% \mathrm{NaCl}$ і 20\% жовчі (Lu \& McMahon, 2015).

L. rhamnosus характеризується наданням добрих реологічних властивостей, стійкістю до солі та інгібуючих речовин молока. Порівняно із мезофільними лактококами протеолітична активність L. rhamnosus в 2 рази вища. Гранична кислотність у молоці сягає $180^{\circ} \mathrm{T}$. Висока здатність до накопичення розчинних білкових сполук із низькою молекулярною масою дає змогу уникнути формування гіркого присмаку в готовому продукті, а кількість вільних амінокислот $є$ достатньою для досягнення зрілості сиру. Штам утворює нев'язкий молочний згусток з показником синерезису 50\% та незначним відходом білкових сполук у сироватку. Такі показники гарантують формування сирного зерна з інтенсивним відділенням сироватки та мі- німізують втрати сухих речовин завдяки утворенню сирного пилу.

Дослідження щодо використання L. rhamnosus у виробництві сирів в нашій країні не проводились, тому важливо дослідити, як вказана культура впливає не лише на тривалість зберігання сиру, а й на перебіг біохімічних процесів і відповідно формування властивостей готового продукту.

\section{Матеріал і методи досліджень}

Матеріалом досліджень слугувала бринза, яка виготовлена з 20 і 30\% заміною кухонної солі хлоридом калію і використанням біозахисної культури.

Було виготовлено 6 зразків бринзи з овечого молока: К - контрольний зразок із використанням кухонної солі (хлорид натрію); Д1 і Д2 - бринза, що виготовлена 320 і $30 \%$ заміною хлориду натрію хлоридом калію відповідно; КF - бринза, що виготовлена із використанням хлориду натрію та біозахисної культури Fresh-Q; ДF1 і ДF2 - бринза, що виготовлена з 20 і 30\% заміною хлориду натрію хлоридом калію відповідно та використанням Fresh-Q.

Дріжджі та плісняві гриби досліджували згідно 3 вимогами ГОСТ 10444.12-88 Пищевые продукты. Методы определения дрожжей и плесневых грибов (Продукти харчові. Методи визначення дріжджів і пліснявих грибів).

\section{Результати та їх обговорення}

Важливо було також дослідити вплив біозахисної культури на формування органолептичних характеристик бринзи. У таблиці 1 наведено результати досліджень бринзи з овечого молока за 20\% і $30 \%$ заміни хлориду натрію хлоридом калію.

Варто підкреслити, що застосування біозахисної культури Fresh-Q зумовлює більший вплив на органолептичні властивості порівняно із заміною кухонної солі. Зокрема, можна виділити вершковий смак зразків бринзи з використанням цієї культури.

За результатами балової оцінки найбільшу кількість балів отримали зразки з використанням Fresh-Q. Бринзу можна віднести до сиру високої якості (табл. 2).

\section{Таблиця 1}

Органолептичні показники бринзи за часткової заміни хлориду натрію хлоридом калію

\begin{tabular}{|c|c|c|c|c|c|}
\hline $\begin{array}{l}\text { Зра- } \\
\text { зок }\end{array}$ & Смак і запах & Консистенція & Рисунок & Колір & Зовнішній вигляд \\
\hline K & $\begin{array}{l}\text { Чистий кисломолочний, в } \\
\text { міру солоний, без сторонніх } \\
\text { присмаків та запахів }\end{array}$ & $\begin{array}{l}\text { Однорідна, } \\
\text { ламка, але не } \\
\text { крихка }\end{array}$ & $\begin{array}{l}3 \text { поодинокими } \\
\text { вічками неправи- } \\
\text { льної форми }\end{array}$ & $\begin{array}{l}\text { Слабо-жовтий, } \\
\text { однорідний за } \\
\text { всією масою }\end{array}$ & $\begin{array}{l}\text { Поверхня чиста, } 3 \text { відбит- } \\
\text { ками серветки. Кірка від- } \\
\text { сутня }\end{array}$ \\
\hline Д1 & $\begin{array}{l}\text { Чистий кисломолочний, в } \\
\text { міру солоний, без сторонніх } \\
\text { присмаків та запахів }\end{array}$ & $\begin{array}{l}\text { Однорідна, } \\
\text { ламка, але не } \\
\text { крихка }\end{array}$ & $\begin{array}{l}3 \text { поодинокими } \\
\text { вічками неправи- } \\
\text { льної форми }\end{array}$ & $\begin{array}{l}\text { Слабо-жовтий, } \\
\text { однорідний за } \\
\text { всією масою }\end{array}$ & $\begin{array}{l}\text { Поверхня чиста, з відбит- } \\
\text { ками серветки. Кірка від- } \\
\text { сутня. Незначна деформа- } \\
\text { ція головки }\end{array}$ \\
\hline Д2 & $\begin{array}{l}\text { Чистий кисломолочний, в } \\
\text { міру солоний, без сторонніх } \\
\text { присмаків та запахів }\end{array}$ & $\begin{array}{l}\text { Однорідна, } \\
\text { ламка, але не } \\
\text { крихка }\end{array}$ & $\begin{array}{l}3 \text { поодинокими } \\
\text { вічками неправи- } \\
\text { льної форми }\end{array}$ & $\begin{array}{l}\text { Слабо-жовтий, } \\
\text { однорідний за } \\
\text { всією масою }\end{array}$ & $\begin{array}{l}\text { Поверхня чиста, з відбит- } \\
\text { ками серветки. Кірка від- } \\
\text { сутня. Незначна деформа- } \\
\text { ція головки }\end{array}$ \\
\hline
\end{tabular}


Продовж. табл. 1

\begin{tabular}{|c|c|c|c|c|c|}
\hline $\begin{array}{l}\text { Зра- } \\
\text { зок }\end{array}$ & Смак і запах & Консистенція & Рисунок & Колір & Зовнішній вигляд \\
\hline$\overline{\mathrm{KF}}$ & $\begin{array}{l}\text { Чистий } \\
\text { вершковий, в міру солоний, } \\
\text { без сторонніх присмаків та } \\
\text { запахів }\end{array}$ & $\begin{array}{l}\text { Однорідна, } \\
\text { ламка, але не } \\
\text { крихка }\end{array}$ & $\begin{array}{l}3 \text { поодинокими } \\
\text { вічками неправи- } \\
\text { льної форми }\end{array}$ & $\begin{array}{l}\text { Слабо-жовтий, } \\
\text { однорідний за } \\
\text { всією масою }\end{array}$ & $\begin{array}{l}\text { Поверхня чиста, з відбит- } \\
\text { ками серветки. Кірка від- } \\
\text { сутня. Незначна деформа- } \\
\text { ція головки }\end{array}$ \\
\hline ДF1 & $\begin{array}{l}\text { Чистий кисломолочний, } \\
\text { вершковий, в міру солоний, } \\
\text { без присмаків }\end{array}$ & $\begin{array}{l}\text { Однорідна, } \\
\text { ламка, але не } \\
\text { крихка }\end{array}$ & $\begin{array}{l}3 \text { поодинокими } \\
\text { вічками неправи- } \\
\text { льної форми }\end{array}$ & $\begin{array}{l}\text { Слабо-жовтий, } \\
\text { однорідний за } \\
\text { всією масою }\end{array}$ & $\begin{array}{l}\text { Поверхня чиста, } 3 \text { відбит- } \\
\text { ками серветки. Кірка від- } \\
\text { сутня }\end{array}$ \\
\hline ДF2 & $\begin{array}{l}\text { Чистий кисломолочний, } \\
\text { вершковий, в міру солоний, } \\
\text { без сторонніх присмаків та } \\
\text { запахів }\end{array}$ & $\begin{array}{l}\text { Однорідна, } \\
\text { ламка, але не } \\
\text { крихка }\end{array}$ & $\begin{array}{l}3 \text { поодинокими } \\
\text { вічками неправи- } \\
\text { льної форми }\end{array}$ & $\begin{array}{l}\text { Слабо-жовтий, } \\
\text { однорідний за } \\
\text { всією масою }\end{array}$ & $\begin{array}{l}\text { Поверхня чиста, з відбит- } \\
\text { ками серветки. Кірка від- } \\
\text { сутня. Незначна деформа- } \\
\text { ція головки }\end{array}$ \\
\hline
\end{tabular}

Таблиця 2

Балова оцінка бринзи

\begin{tabular}{lccccccc}
\hline \multirow{2}{*}{\multicolumn{1}{c}{ Показник }} & Максимальна & \multicolumn{7}{c}{ Зразки бринзи } \\
\cline { 2 - 8 } & кількість балів & К & Д1 & Д2 & КF & ДF1 & ДF2 \\
\hline Смак і запах & 45 & 43 & 43 & 43 & 43 & 43 & 42 \\
Консистенція & 25 & 22 & 22 & 23 & 24 & 24 & 23 \\
Рисунок & 10 & 8 & 8 & 8 & 9 & 8 & 9 \\
Колір сирного тіста & 5 & 5 & 5 & 5 & 5 & 5 & 5 \\
Зовнішній вигляд & 10 & 7 & 7 & 8 & 8 & 8 & 9 \\
Сума балів & 95 & 85 & 85 & 87 & 89 & 88 & 88 \\
\hline
\end{tabular}

У таблиці 3 показано фізико-хімічні показники зрілого сиру бринза (20 діб). Звертаємо увагу на активну кислотність: зразки з використанням препарату Fresh-Q відзначаються нижчою кислотністю сирного тіста, ніж аналогічні зразки без препарату. Найвищою масовою часткою вологи $(53,1 \%)$ характеризується контрольний зразок, а найнижчим - зразок з 20\% заміною хлориду натрію хлоридом калію. Зауважуємо також, що найвищий вміст $\mathrm{NaCl}$ у зрілій бринзі характерний для контрольного зразка, у дослідних зразках він на 0,82-0,97\% менший. Це забезпечує зниження споживання кухонної солі при добовій нормі споживання сиру (70 г) (Ayyash et al., 2012).

Таким чином, заміна кухонної солі і застосування препарату Fresh-Q забезпечує високу якість продукту і відповідність його вимогам нормативної документації (DSTU 7065:2009, 2010). Важливо було також дослідити виживання молочнокислих бактерій під час зберігання зрілої бринзи.

Таблиця 3

Фізико-хімічні показники зрілої бринзи за часткової заміни хлориду натрію хлоридом калію $(\mathrm{n}=3, \mathrm{P}<0,05)$

\begin{tabular}{|c|c|c|c|c|c|}
\hline \multirow{2}{*}{$\begin{array}{l}\text { Зразки } \\
\text { бринзи }\end{array}$} & \multicolumn{5}{|c|}{ Показники } \\
\hline & $\begin{array}{l}\text { Масова частка жиру } \\
\text { в сухій речовині, \% }\end{array}$ & $\begin{array}{c}\text { Масова частка } \\
\text { вологи, \% }\end{array}$ & $\begin{array}{c}\text { Масова частка } \\
\mathrm{NaCl}+\mathrm{KCl}, \%\end{array}$ & $\begin{array}{c}\text { Масова частка } \\
\mathrm{NaCl}, \%\end{array}$ & $\begin{array}{c}\text { Активна кислотність, } \\
\text { одиниць рН }\end{array}$ \\
\hline $\mathrm{K}$ & $45,9 \pm 0,3$ & $53,1 \pm 0,2$ & $4,2 \pm 0,1$ & $4,20 \pm 0,1$ & $4,23 \pm 0,03$ \\
\hline Д1 & $44,3 \pm 0,3$ & $52,2 \pm 0,3$ & $4,3 \pm 0,2$ & $3,44 \pm 0,2$ & $4,22 \pm 0,02$ \\
\hline Д2 & $45,8 \pm 0,2$ & $52,4 \pm 0,3$ & $4,1 \pm 0,1$ & $3,28 \pm 0,1$ & $4,33 \pm 0,03$ \\
\hline KF & $45,1 \pm 0,4$ & $51,7 \pm 0,2$ & $4,3 \pm 0,1$ & $4,30 \pm 0,1$ & $4,12 \pm 0,02$ \\
\hline ДF1 & $43,9 \pm 0,3$ & $51,0 \pm 0,3$ & $4,2 \pm 0,2$ & $3,36 \pm 0,2$ & $4,10 \pm 0,02$ \\
\hline ДF2 & $44,8 \pm 0,4$ & $51,3 \pm 0,2$ & $4,3 \pm 0,2$ & $3,44 \pm 0,2$ & $4,08 \pm 0,03$ \\
\hline
\end{tabular}

Результати досліджень показано на рисунку 1. Протягом 50 діб кількість молочнокислої мікрофлори знижується, проте спостерігається тенденція до вищих значень за 20 та 30\% заміни кухонної солі хлоридом калію та використання препарату Fresh-Q. Зразки бринзи із препаратом Fresh-Q вирізнялися істотно вищим рівнем КУО молочнокислих бактерій.

Оскільки біозахисна культура згубно впливає на розвиток дріжджів і пліснявих грибів, то наші дослідження полягали саме у виявленні цих мікроорганізмів у товщі бринзи та на поверхні.

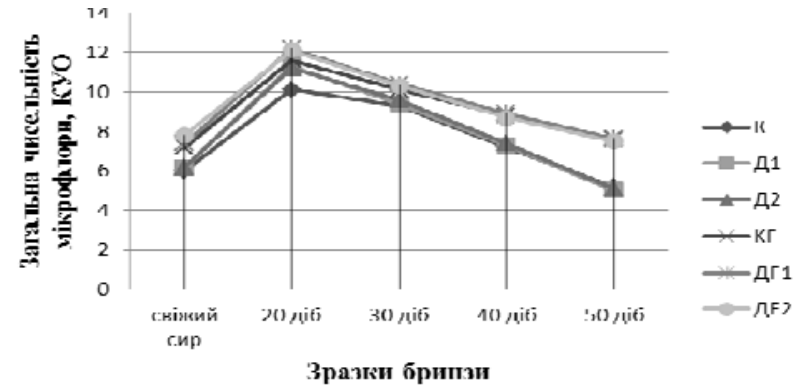

Рис. 1. Зміна чисельності молочнокислої мікрофлори під час зберігання бринзи 
Найсприятливіші умови для розвитку плісені - вільний доступ кисню i кисле середовище $(\mathrm{Lu} \&$ McMahon, 2015). Вона може розвиватися при $\mathrm{pH}$ $1,5 \ldots 11,0$, витримує низьку температуру $(-11 \pm 1){ }^{\circ} \mathrm{C}$. Плісняві гриби володіють ферментативною активністю, сприяють неконтрольованому розпаду білків та білкових речовин, жирів до жирних кислот та альдегідів і, як наслідок, появі вад. У результаті своєї життєдіяльності плісняві грибки метаболізують компоненти харчових продуктів, утворюючи власні специфічні продукти метаболізму. При цьому фізико-хімічні та органолептичні показники змінюються і продукт набуває нехарактерних особливостей, що погіршують його якість (Skulska \& Cisaryk, 2015). Наявність пліснявих грибів та дріжджів у сирі видно неозброєним оком. В такому випадку на поверхні брусочків може спостерігатися наліт білого кольору зі злегка сіруватим відтінком. Важливо зазначити, що використання біозахисної культури Fresh-Q згубно діяло на розви- ток плісені. Присутності останньої у зразках, які виготовлені з Fresh-Q, не було виявлено протягом усього періоду визрівання та у зрілому сирі і під час подальшого зберігання. На 45 добу (табл. 4) помітна поява плісені у сирах групи без препарату Fresh-Q, а для групи сирів 3 Fresh-Q появу плісені помітно на 55 добу зберігання.

Отже, часткова заміна $\mathrm{NaCl}$ на $\mathrm{KCl}$ при використанні препарату Fresh-Q, який пригнічує розвиток дріжджів та плісені, сприяє подовженню терміну зберігання сиру.

У табл. 5 показано оцінку бринзи на наявність плісені, оціненої візуально.

Аналіз посівів (табл. 6) засвідчує, що на 45 добу у зразках бринзи без Fresh-Q кількість КУО дріжджів і плісені становила понад 10 у 1 г, тоді як у зразках із препаратом Fresh-Q така кількість з'являється на 55 добу, що, безумовно, доводить доцільність використання захисної культури.

\section{Таблиця 4}

Наявність небажаної мікрофлори на поверхні бринзи

\begin{tabular}{|c|c|c|c|c|c|c|c|c|c|c|c|c|}
\hline \multirow{2}{*}{ Зразок } & \multicolumn{12}{|c|}{ Доби зберігання } \\
\hline & 10 & 15 & 20 & 25 & 30 & 35 & 40 & 45 & 50 & 55 & 60 & 65 \\
\hline K & - & - & - & - & - & - & - & + & + & + & + & + \\
\hline Д1 & - & - & - & - & - & - & - & + & + & + & + & + \\
\hline Д2 & - & - & - & - & - & - & - & + & + & + & + & + \\
\hline $\mathrm{KF}$ & - & - & - & - & - & - & - & - & - & + & + & + \\
\hline ДF1 & - & - & - & - & - & - & - & - & - & + & + & + \\
\hline ДF2 & - & - & - & - & - & - & - & - & - & + & + & + \\
\hline
\end{tabular}

Таблиця 5

Наявність плісені та дріжджів у товщі бринзи

\begin{tabular}{|c|c|c|c|c|c|c|c|c|c|c|c|c|}
\hline \multirow{2}{*}{ Зразок } & \multicolumn{12}{|c|}{ Доби зберігання } \\
\hline & 10 & 15 & 20 & 25 & 30 & 35 & 40 & 45 & 50 & 55 & 60 & 65 \\
\hline $\mathrm{K}$ & - & - & - & - & - & - & - & $>10$ & $>10$ & $>10$ & $>10$ & $>10$ \\
\hline Д1 & - & - & - & - & - & - & - & $>10$ & $>10$ & $>10$ & $>10$ & $>10$ \\
\hline Д2 & - & - & - & - & - & - & - & $>10$ & $>10$ & $>10$ & $>10$ & $>10$ \\
\hline $\mathrm{KF}$ & - & - & - & - & - & - & - & - & - & $>10$ & $>10$ & $>10$ \\
\hline ДF1 & - & - & - & - & - & - & - & - & - & $>10$ & $>10$ & $>10$ \\
\hline ДF2 & - & - & - & - & - & - & - & - & - & $>10$ & $>10$ & $>10$ \\
\hline
\end{tabular}

\section{Висновки}

Таким чином, за органолептичними показниками бринза повністю відповідає вимогам діючої нормативної документації. Дослідження перебігу мікробіологічних процесів підтверджують доцільність удосконалення традиційної технології виготовлення бринзи шляхом часткової заміни кухонної солі хлоридом калію та додавання препарату Fresh-Q. Встановлено, що термін зберігання сиру подовжується на 10 діб у зразків, які виготовлені з використанням біозахисної культури Fresh-Q.

\section{References}

Ayyash, M.M., \& Shah, N.P. (2011). Proteolysis of lowmoisture Mozzarella cheese as affected by substitution of $\mathrm{NaCl}$ with $\mathrm{KCl}$. Journal of Dairy Science, 94(8), 3769-3777. doi: 10.3168/jds.2010-4104.
Ayyash, M.M., \& Shah, N.P. (2011). The effect of substituting $\mathrm{NaCl}$ with $\mathrm{KCl}$ on Nabulsi cheese: chemical composition, total viable count, and texture profile. Journal of Dairy Science, 94, 2741-2751. doi: 10.3168/jds.2010-3976.

Ayyash, M.M., Sherkat, F., \& Shah, N.P. (2012). The effect of $\mathrm{NaCl}$ substitution with $\mathrm{KCl}$ on Akawi cheese: Chemical composition, proteolysis, angiotensinconverting enzyme-inhibitory activity, probiotic survival, texture profile, and sensory properties. Journal of Dairy Science, 95(9), 4747-4759. doi: 10.3168/jds.2011-4940.

Brynza zi znyzhenym vmistom kuhonnoji soli (2016). Tehnichni umovy 10.5-00492990-013:2016. Chynnyj vid 14.05. 2016. Lviv, Derzhspozhyvstandart Ukrajiny (in Ukrainian).

DSTU 7065:2009 (2010). Brynza. Zahalni tehnichni umovy: BZ № 10-2009/789. Vydannya oficijne. Ky- 
jiv: DERZHSPOZHYVSTANDART Ukrajiny (in Ukrainian).

Grummer, J., Bobowski, N., Karalus, M., Vickers, Z., \& Schoenfuss, T. (2013). Use of potassium chloride and flavor enhancersin low sodium Cheddar cheese. Journal of Dairy Science, 96(3). 1401-1418. doi: 10.3168/jds.2012-6057.

Gudkov, A.V. (2003). Syrodelie: tehnologicheskie i fiziko-himicheskie aspekty. Moskva (in Russian).

Kamleh, R., Olabi, A., Toufeili, I., Najm, N.E.O., Younis, T., \& Ajib, R. (2012). The effect of substitution of sodium chloride with potassium chloride on thephysicochemical, microbiological, and sensory properties of
Halloumi cheese. Journal of Dairy Science, 95. 11401151. doi: 10.3168/jds.2011-4878.

Lu, Y., \& McMahon, D.J. (2015). Effects of sodium chloride salting and substitution with potassium chloride on whey expulsion of Cheddar cheese. Journal of Dairy Science, 98(1), 78-88. doi: 10.3168/jds.2014-8600.

Skulska, I.V., \& Cisaryk, O.J. (2015). Doslidzhennja mikrobiologichnyh pokaznykiv brynzy, shho vygotovlena $\mathrm{z}$ chastkovoju zaminoju hlorydu natriju hlorydom kaliju. Prodovolchi resursy: zb. nauk.. pr. NAAN Ukrajiny; In-t prod. resursiv NAAN Ukrajiny. Kyjiv, 4, 58-62 (in Ukrainian). 